\title{
An Evaluation of How Educators in Virtual Teams Perceive Charismatic Leadership During the COVID-19 Crisis
}

\author{
Latifa Attieha $^{1^{*}}$, Omar Zouhairy $^{2}$ \\ 1*Modern University for Business \& Science, Beirut, Lebanon \\ ${ }^{2}$ Cardiff Metropolitan University, Wales, United Kingdom
}

\section{Keywords: \\ Charismatic, Leadership, COVID-19}

\section{Received}

29 December 2021

Received in revised form

25 January 2021

Accepted

25 February 2021

*Correspondence:

lattieh@mubs.edu.lb

\begin{abstract}
Leadership constituted a topic of high interest for researchers and practitioners alike for years. Numerous studies have focused on leadership styles, particularly charismatic leadership, as an antecedent to organizational achievements. However, most researchers neglected to consider the followers' perception of their leader's performance. Understanding and accommodating the needs of the followers is essential to the leader's success. The current study investigates the influence of charismatic leaders on dispersed teams in non-vocational educational institutions in Lebanon. This quantitative study utilized two structured questionnaires to investigate the charismatic leadership during the COVID-19 crisis from the perspective of educators who work in virtual teams. Five hypotheses on the effect of crisis-bound charismatic leadership on distant educational teams were tested. The relation between the number of years of experience and charisma was not explored since the majority of respondents fell in the category of five years or more at the institution. A total of seventy-seven respondents completed the survey online. Statistical analysis, using the software SPSS-23, showed that neither gender nor level of education affected the followers' perception of charismatic leadership during crises. Nonetheless, the study findings showed a strong positive correlation between charismatic leadership and the ability to lead in a crisis, concluding that charismatic leaders emerge in times of stress.
\end{abstract}

CCIKD Publishing

Leadership in organizations is a subject that has excited the interest of researchers in the past few decades. The term 'leader' demonstrates a connotation of power, dynamism, and command in mind. The introduction of charisma as a major variable in effective leadership intrigued many researchers to dive into the realm of this seemingly indescribable characteristic. A charismatic individual is always associated with the description of a skilled orator demonstrating a clear vision (Yukl, 2013). Charisma was first introduced in the 1920s by the German sociologist Max Weber; however, his 
ideas were too theoretical. In the 1970s, Robert House transformed the theory of charismatic leadership into a more testable concept. In short, this theory tries to explain the reasons that cause followers of a certain leader to willingly exert remarkable effort and make personal sacrifices to reach the organization's goals (Luenendonk, 2020). The literature includes several research publications on the effect of charisma on the efficiency and effectiveness of organizational leadership (Cherulnik et al., 2001; Davis, \& Gardner, 2012; Gardner, 2003; Vergauwe et al., 2018). Conger and Kanungo (1987) offered a theory of charismatic leadership while assuming that charisma is an attributional phenomenon. As technological advancement excelled and globalization spread with the birth of the twenty-first century, leadership faced one of its biggest hurdles; managing virtual teams. The influence imposed by a charismatic leader can be easily detected when in direct communication with his/her subordinates. However, charismatically governing a team in a different city or even in a different country can prove to be quite challenging (Hoch \& Dulebohn, 2017).

This research investigates the influence of charismatic leaders on dispersed teams in nonvocational educational institutions in Lebanon. With the conclusion of the year 2019, a viral outbreak started to threaten the health of humans in many countries. In 2020, the threat spread, leading to a global COVID-19 pandemic. One of its major implications was a national lockdown whereby people stayed quarantined and were obliged to work remotely. Consequently, universities were obliged to transform their optional distance learning preference into the current compulsory norm. Administrative leaders had to act fast and address newly born challenges and, at the same time, were compelled to manage their academic staff remotely (Fernandez \& Shaw, 2020b).

\section{Leadership in Literature}

Early theories focused on the characteristics of a successful leader, while later ones considered the role of the followers and the nature of leadership (Bolden et al., 2003). The trait approach considered that critical leadership characteristics should be present in a person in order for him or her to be recruited into a leadership role (Yaslioglu \& SelenayErden, 2018). This concept faced a large amount of criticism as research could not be consistent in identifying these traits. It was abandoned until the emergence of charisma as the main ingredient of contemporary leadership (Alimo-Metcalfe, 2013). As investigation into the importance of management in corporations gained further interest, the research on Leadership evolved from the trait approach to the leadership style trend, which focused on leader behavior (Salehzadeh, 2017). Again, research did not find any consistent patterns regarding the effect of these behavioral styles on essential variables such as employee satisfaction, effectiveness, and productivity (House, 1971; Larson et al., 1974; Yukl, 2013).

One of the main limitations of behavioral theories was its inability to adapt effective leadership to different situations. Research today suggests that the leadership style is contingent upon the surrounding environmental variables, including the situations at hand, the people involved, and the time available to complete tasks. Situational models encourage flexibility in style depending on the situations faced (Fiedler, 1964, 1967; Fiedler \& Chemers, 1974; Hidayat et al., 2020). Moreover, successful leadership relies on matching the proper personality to the situation and not the opposite (Northouse, 2010). One of the main critical approaches to this theory stated that if his theory were true, then individuals with leadership roles in organizations should be rotated around the organization as tasks and situations changed, which is impractical (Nastiezaie \& Musavinejad, 2018). 
At the dawn of the last decade of the twentieth century, researchers recognized that managers and leaders are two separate entities and that there was a surplus of the former and a shortage of the latter (Zaleznik, 1990). A leader can be identified either by who he is or by the actions, responsibilities, and obligations he endows (Epley, 2015). Leadership was classified as being transactional or transformational. In the current era, successful organizations have adopted teamoriented practices. The key to success resides in a strong team leader with a clear vision and a skill to convey it to the followers to gain their commitment and motivate them to work efficiently towards achieving the company goals (Cherry, 2019). Transactional leadership focuses on the performance of the staff members, overlapped by a system of rewards and penalties and the opportunity for upward mobility (Bryant, 2003). The main characteristics of transactional leaders include focusing on short-term goals, following procedures and policies, rejoicing in efficiency, and adamant about changing. They use rewards and punishment to pinpoint strengths and weed out weaknesses among staff. This leadership style cherishes the status quo and if forced into change, will implement within the existing systems and structures (Bass, 2000; Young et al., 2020). On the other hand, transformational leadership is considered the most studied among all theories on leadership (Judge \& Piccolo, 2004). Such leaders have a thirst for change and seem to fundamentally reform the company they head (Kull, 2003). They are portrayed by a compelling vision and influential communication skills that endorse powerful messages into their followers' ideologies. As a result, these followers are inspired to seek the organization's objectives over selfinterest (Kreitner \& Kinicki, 2004; Kwan, 2020). The literature reveals that transformational leaders possess four core behaviors: 1) charisma or idealized influence, 2) inspirational motivation, 3) intellectual stimulation, and 4) individualized consideration (Hyland et al., 2018).

The transformational leadership theory directed the focus on studying how a leader can enhance the performance of his/her team to elevate the levels of accomplishment (Herman, \& Chiu, 2014). In came the concept of charisma, which appeared first in Max Weber's 1974 research work (Joosse, 2014). He described a charismatic leader as exceptional and has the vision to find a solution for crises, attracting followers through his character and behavior to reach repeated success. Most theories of charisma focused on how leaders change people instead of responding to them (House et al., 1997; Meslec et al., 2020). In a sense, charisma and transformational leadership are analogous, but theoretically they diverge (Antonakis, 2012). Transformational leadership is more comprehensive, depending on influence to reach empowerment. In contrast, charismatic leadership arises from certain character attributions that yield a certain X-factor known as charisma (Meindl et al., 2001).

In the business world, Charisma is associated with leaders showing a dominant personality admired by followers and gaining their trust and devotion (Meindl et al., 2001; Meslec et al., 2020). Such a commanding personality can remodel the work atmosphere and the organization's vision (Northouse, 2010). Many scholars attempted to identify the virtues of charismatic leadership. Beyer (1999) proposed that a leader should have charismatic vision to be deemed outstanding. Other research found supportive evidence that charismatic leadership tends to appear during crisis. Followers admire a leader in action during turbulent times, labeling him charismatic (Crayne \& Medeiros, 2020; Mumford et al., 2008). Followers are considered an essential variable as they associate the charismatic character with those in leadership roles. Since these leaders are behavioral models in an organization, charismatic leadership could be detected at different levels in a corporation; however, the more authoritative the position, the more exposure and greater influence 
(Meindl et al., 2001). Several studies have also tackled the perception of a charismatic leader based on followers' gender or social and educational status. Zhang et al. (2020) studied followers' gender perception of charismatic leaders and the potential negative implications. Other studies have focused on the gender of the leader and its relation to charisma (Brands et al., 2015; Rink et al., 2019).

\section{Charismatic Leadership in Education}

On the topic of leadership in education, the literature concentrated on studying the effect of different leadership styles on educational organizations. One of the major tasks of such leaders is to persuade middle management about the importance of development objectives and the attainment of needed resources (Ozgene, 2020; Schratz , 2009). This requires the presence of a character that blends charisma with confidence. This charismatic approach can be detected from body language, which could be as simple as a warm smile. Avolio and Bass (1995) showed that the language of charismatic personalities attracts followers and aligns them towards the intended mission. Their speeches are usually strong, convincing, and conveying confidence. With this blend, people within the orbit feel safe, happy, and on board (Kominiak, 2016).

With the rising challenges of the twenty-first century, such as innovations in technology and globalization, the roles of educational leaders are radically changing at a spontaneous pace. It is not enough anymore to be a good manager to lead an educational organization into success. The leader's effective and inspirational leadership has become key to large-scale educational improvement (OECD, 2020). Influential leadership requires the proper environment to emerge. Bass and Stogdill (1990) showed that charisma being an exceptional attribute can be perceived differently by followers based on the individual, the exceptional situation at hand, and how they interact. Conger (1989) contemplated that the more favorable the situation to charisma, the less charismatic features needed for a leader to be labeled as charismatic by his followers. Howell (1997) went further to state that people by nature are adamant to change and could feel helpless and frustrated when encountering it and will therefore seek and embrace authority of a charismatic leader.

A proficient and well-supported leadership team can cultivate a sense of ownership and determination in how staff members perform their job. Rewards are consistently ranked among the top incentives for job commitment and satisfaction. Rewards could be classified as either intrinsic or extrinsic and a blend of both has shown to best formula for success. Research shows the more emphatic teachers are towards the decision-making process at the educational institute, the higher the impact and commitment achieved. Teacher moral and materialistic incentive, efficacy, work environment, and professional autonomy are crucial for employee satisfaction in education. Educators, in particular, look up to a charismatic leader who emits honesty, firmness, consistency, influential communication, and reasonable support (Goodboy \& Bolkan, 2011; Hargreaves, 2000; Mulford, 2008).

\section{Charismatic Leadership during the COVID-19 Crisis}

The last quarter of 2019 witnessed the rise of the COVID-19 virus, which, by the year 2020, became the worst pandemic crisis since the Spanish flu (Walsh, 2020). It became the major destabilizer of the world economy affecting global public and private sectors (UNESCWA, 2020). Corporations had little time to counter the repercussions through their crisis management teams and find alternative plans to minimize damage. Leadership styles had to be revisited and altered towards 
adapting to this unprecedented situation. Almost all famous leaders in history have overcome bottleneck situations, but the COVID-19 predicament seems to be prolonged if not an existential endeavor. In such a case, effective leadership is vital for the organization and its people and demands boldness, determination, and sacrifice (VanSlyke \& Simons, 2020).

As the world went into lockdown, many challenges were unleashed towards the organizational workforce. A survey done by Watkins and Yaziji (2020) showed that the industries that were most affected by the crisis were the ones that mainly relied on social interaction, such as travel and tourism, oil and gas, education, and health care. Virtual or dispersed teams became a necessity that drew out further challenges, especially in third world countries where technological facilities are a burden. Virtual teams are usually geographically dispersed and communicate through electronic means with minimal face-to-face interaction. Although dispersed teams appeared with globalization and the internet and many research studies were undertaken to determine their pros and cons, but in 2020, such teams were imposed on businesses, and making them succeed became the number one priority of every organization (Hoch \& Dulebohn, 2017).

With virtual teams, the organization focuses on employee empowerment, mobility, interdependence, and confidence (Yesil, 2011). For such teams to thrive, a common purpose acknowledged by members should be at the core of the group. Due to the absence of direct contact, a clear vision and well-defined goals are essential for gaining virtual employee commitment (Kuscu $\&$ Arslan, 2016). As working from home became the only option, managers lost the privilege of personal supervision of employees on the job and had to revert to virtual leadership. As shown by the literature, the characteristics of a successful virtual leader can be diverse. They include 1) ability to set measures for long-distance team efficiency, 2) ability to give and collect both formal and informal forms of feedback, 3) possession of proper knowledge in educational management systems and technological programs used for communication, 4) ability to host and conduct virtual meetings, and 5) ability to establish and maintain proper relations with distant employees and motivate them to give their maximum efforts (Duarte \& Snyder, 2006; Kirel, 2007). Taking those traits into account, the main concerns of a virtual leader fall into three job specifications: 1) a liaison that links all the team members while maintaining a common environment, 2) a direction setter that ensures that all employees are working in alignment with company purpose and goals, and 3) an operational coordinator who identifies and allocates resources towards developing solutions for any arising dilemma (Mehtab et al., 2017).

"The key to the success of distance learning is the guardian. If the coach is good, the technology becomes almost transparent. On the contrary, no technology can overcome a poor tutorial" (Garcia, 2015, p.3). With the COVID-19 pandemic looming on the horizon, the 2019-2020 academic year was threatened. Educational leaders were placed in a tight position to identify alternatives to survive this critical period with minimal damage to the learning process. Online teaching became an imposed reality instead of an optional luxury. Meindl et al. (2001) showed that leaders and their surroundings are entangled in a complicated and profound fashion.

Looking back at the literature, we find a plethora of articles studying distance education in universities and colleges, but very few tackle the importance and attributes of the leadership navigating such programs (Beaudoin, 2003; Irlbeck, 2002; Olcott, 2020). Distance education leaders are the key to the success of distance education as they oversee the evolution of new practices that go hand in hand with the ongoing technological development. Such trends call for specific skills for the leader to impose well-rounded change instead of relying on traditional systems 
and processes that would likely fail to adapt to the current critical situation. They have to operate in a rapidly changing environment withstanding the pressure inflicted by the human instinct of resistance to change (Otte \& Benke, 2006). Forceful leadership is crucial to set forth the change while preventing chaos, minimizing waste of valuable resources, and serving learners with the best possible means (Nworie et al., 2012). Now distance learning needs to cater to an adaptive phase for traditional learners who did not choose to shift to online learning. Even in a virtual setting, motivating followers and gaining commitment is imminent, especially that the physical presence of the motivator is missing. In virtual teams, the leader aims to establish a sense of cohesion and consistency in his team and learners that contribute to the given task. He should be proactive and interactive and create strategies that build a profound incentive to reach success (Gunasekare, 2016).

Several studies have already been published on the effect of the COVID-19 pandemic on education and the obligatory transition towards remote learning (Fauzi \& Khusuma, 2020; Mascolo, 2020; Owusu-Fordjour et al., 2020). Resorting towards online learning sheds effect on all stakeholders within educational institutes, imposing quick adaptive measures, especially since many institutions lack the needed digital infrastructure. Teachers, staff, students, and parents were in uncharted territory, stressing that a radical change was taking place to save the academic year. To instill some assurance and comfort, academic leaders had to intervene using their inspirational influence, intellectual stimulation, and idealized influence (Almaiah et al., 2020; Fernandez \& Shaw, 2020a, 2020b). As charismatic leaders are well known for their thirst for innovation and divergence from the status quo, this crisis seemed like the perfect window of opportunity for them to gain a competitive advantage over adversary and harvest success. Such leaders will also assess the importance of this change in the short run and the long run. The crisis will eventually be over, presenting a new dilemma of working on and enhancing remote learning or finding some hybrid mix between traditional learning and technology. Due to the social distancing practices and location dispersal, the leader should communicate with his team frequently and clearly (Edmondson, 2020). Several communication channels should be made available considering the preferences of different stakeholders and the ease of operations. Communication in a crisis is sensitive and should be tactfully crafted (Almanthari et al., 2020; Field, 2020; Robbins \& Judge, 2018). The academic leader should show credibility and transparency in his actions during a crisis. The campus community should have a clear idea of where the institution is heading. Vagueness and uncertainty generate panic, and thereby, the academic leader should not radiate any sort of ambiguity towards

his followers. Learning from hurdles and overcoming them is an essential ingredient of effective leadership (Fernandez \& Shaw, 2020a).

\section{Methodology}

This study evaluated the impact of charismatic leadership, E-learning, and the COVID-19 crisis on each other to explain the patterns of relationships among them. The primary data was acquired through quantitative methods using a survey. The surveys chosen for this research was delivered electronically through a cloud-based platform, and participation was voluntary. Participants were randomly selected from several non-vocational universities around Lebanon. The selection process was done by convenience since the country was passing through several crises (Social, Economic, Political, and Medical) at the time of conduction of this study. The sample included professors, lecturers, instructors, and teaching assistants. All participants held a bachelor's degree or higher. The time frame for answering the survey was extended for one month, between September 10, 2020 
and October 10, 2020. The data analysis was done using the Statistical Package for Social Science (SPSS v. 23).

This study tested five hypotheses on the effect of crisis-bound charismatic leadership on distant educational teams. The relation between the number of years of experience and charisma was not explored since the majority of respondents fell in the category of five years or more at the institution. The hypotheses are:

$\mathbf{H}_{1}$ : In virtual teams, male educators perceive their leaders as more charismatic than female educators do.

H2: In virtual teams, male educators perceive their leaders as capable of handling a crisis more than female educators do.

H3: In virtual teams, the higher the level of education of the subordinate, the less he/she perceives their leader as charismatic.

H4: In virtual teams, the higher the level of education of the subordinate, the less he/she perceives the leader as capable of handling crisis.

Hs: In virtual teams, the charisma of the leader is positively correlated with his/her ability to lead in crisis.

Hypotheses 1 and 2 were analyzed using the T-test since the only variable considered was gender. Hypotheses 3 and 4 were analyzed using the One-way ANOVA to determine relationships among several variables. For hypothesis 5, the Pearson's correlation coefficient was used to measure the statistical association between the two variables, charismatic leadership and leading in crisis.

Two instruments were used in this research by combining them into one survey. The first was the C-K Charismatic Leadership Scale, copyrighted by Conger and Kanungo (Meindl et al., 2001). Conger granted written consent to the use of their instrument in this study and its adaptation to the context of our research. According to Conger and Kanungo (1987), the CK Charismatic Leadership Scale is considered highly reliable with a Cronbach alpha value of 0.88 . The second instrument, the Crisis Leadership Self-Assessment survey, was obtained from the Center for Creative Leadership (CCL), an organization specialized in cultivating leaders (Center for Creative Leadership, 2020).

The first section of the survey consisted of questions targeting demographic information such as gender, age, and social and educational status. The middle section consisted of the 25 -item CK Charismatic Leadership Scale. It measured the respondent's understanding of their immediate manager or supervisor's strategic vision and articulation, sensitivity to the surrounding and subordinates' needs, personal risk, and unconventional behavior (Meindl et al., 2001). The questions were specifically adapted to leadership in higher education. The last part of the instrument included 15 questions that measured the respondents' perception of their leaders during times of crisis, in particular the COVID-19 pandemic.

Except for the demographic part, all questions in the survey used a six-point Likert scale of measurement ranging from "Strongly Agree" to "Strongly Disagree". A 6-point scale was intended to remove the neutral option from the survey, which is usually considered the easy way out to respondents who do not want to put effort into specific questions. Thereby, respondents were forced to choose between positive or negative answers, giving our data a better perspective. 


\section{Results}

A total of seventy-seven responses were collected. As indicated in Table 1, 62.3\% were female participants, while $37.7 \%$ were males. More than half of the educators surveyed $(50.6 \%)$ were within 36-45 years. Concerning the level of education reached, $45.5 \%$ were holders of a PhD., 44.2\% had a Master's degree, while 10.4\% held a Bachelor Degree. Moreover, approximately $72 \%$ of the respondents had been working in the institution for five years or more (Table 1).

Table 1

The Demographics of the Sample

\begin{tabular}{llcc}
\hline Variable & Dimensions & Frequency & Percentage \\
\hline Gender & Female & 48 & 62.3 \\
& Male & 29 & 37.7 \\
Age Group & $18-25$ Years & 3 & 3.9 \\
& 26-35 Years & 17 & 22.1 \\
& $36-45$ Years & 39 & 50.6 \\
& $46-55$ Years & 13 & 16.9 \\
& 56+ Years & 5 & 6.5 \\
Level of Education & Bachelor Degree & 8 & 10.4 \\
& Master's Degree & 34 & 44.2 \\
& PhD/MD & 35 & 45.5 \\
Years of Employment at Current & 1 Year & 3 & 3.9 \\
Institution & 2 Years & 5 & 6.5 \\
& 3 Years & 8 & 10.4 \\
& 4 Years & 5 & 6.5 \\
Total & 5+ Years & 56 & 72.7 \\
\hline
\end{tabular}

The first hypothesis $\left(\mathrm{H}_{1}\right)$ in our study assumed that male educators in distant teams still perceive their leaders as more charismatic than their female counterparts. This hypothesis studied one variable, the gender of the follower, and thereby was assessed using an independent T-test. According to the group statistics, in distant teams, male educators $(M=4.60, S D=.94)$ found their leaders more charismatic than female educators $(M=4.48, S D=.81)$ did. However, Levene's Test showed that the difference was not significant, $p=.63, p>.05$ (Table 2).

Table 2

Levene's Test for Equality of Variances: Testing the Relation between Followers' Gender and their Perception of Charismatic Leaders

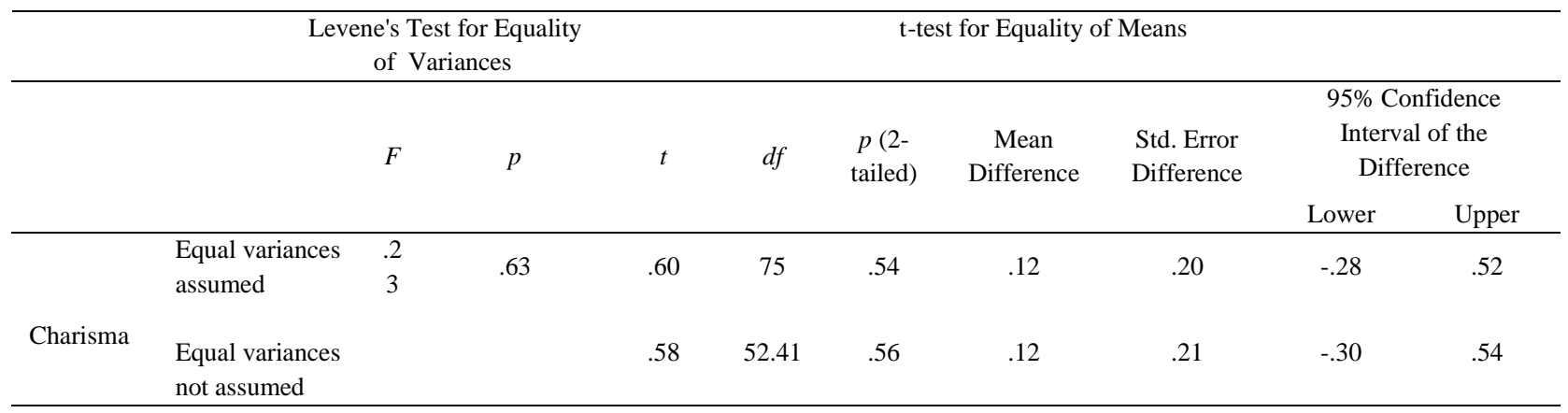

The second hypothesis $\left(\mathrm{H}_{2}\right)$ examined the relationship between the leader's performance during the crisis and how male and female educators perceive this performance. The T-test showed that females $(M=4.83, S D=.93)$ perceive their leader as successful slightly more than male educators $(M=4.78, S D=1.09)$ do. Again, Levene's test $(p=.75)$ showed that this difference is not significant (Table 3 ). 
Table 3

Levene's Test for Equality of Variances: Testing the Relation between Followers' Gender and their Perception of Leader's Performance during Crisis

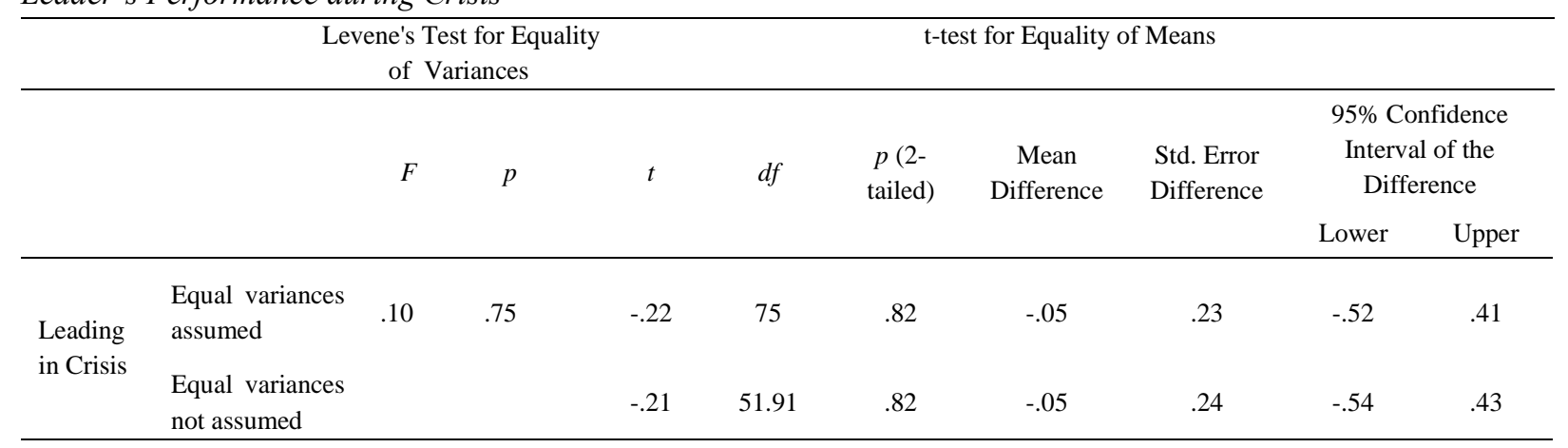

The third hypothesis $\left(\mathrm{H}_{1}\right)$ assumed that followers' level of education affects their perception of their leader's charisma. A one-way ANOVA test was utilized to analyze the three groups of respondents. Holders of a Bachelor degree $(M=5.01, S D=.43)$ perceived their leaders as charismatic more than their counterparts holding a Master's degree $(M=4.55, S D=.81)$ or a $\mathrm{PhD}$ $(M=4.39, S D=.94)$ did. However, this difference among the three groups is not significant $(p=$ $.18, p>.5$ ). Thus, the hypothesis is not accepted (Table 4).

Table 4

One-way ANOVA Test: Testing the Relation Between the Educational Level of the Followers and their Perception of Charismatic Leaders

\begin{tabular}{lcccc}
\hline Charisma & $S S$ & $d f$ & $M S$ & $F$ \\
\hline Between Groups & 2.54 & 2 & 1.27 & 1.74 \\
Within Groups & 53.85 & 74 & .72 & .18 \\
Total & 56.40 & 76 & & \\
\hline
\end{tabular}

The fourth hypothesis $\left(\mathrm{H}_{4}\right)$ tested the relation between the followers' level of education and their perception of their leaders' performance during the crisis. Educators in virtual teams holding a Bachelor degree $(M=5.29, S D=.42)$ perceived their leaders as more able to lead in crisis, in comparison with educators holding a Master's degree $(M=4.86, S D=1.00)$ or a $\operatorname{PhD}(M=4.65$, $S D=1.05)$. The one-way ANOVA test evaluated the difference among the three groups, showing that it was not significant $(p=.24)$ (Table 5).

Table 5

One-way ANOVA Test: Testing the Relation between the Educational Level of the Followers and their Perception of their Leader's Performance during Crisis

\begin{tabular}{lcccc}
\hline & $S S$ & $d f$ & $M S$ & $p$ \\
\hline Between Groups & 2.80 & 2 & 1.40 & .24 \\
Within Groups & 72.26 & 74 & .97 & 1.43 \\
Total & 75.06 & 76 & & \\
\hline
\end{tabular}

The normality of the two variables, the Charisma of the leader and the ability to lead in crisis, was evaluated before analyzing the data. After removing the outliers, the data was designated as normal. As shown in Table 6, the hypothesis is accepted since the significance (2-tailed) is less than .05. Moreover, the positive correlation between the two variables is strong (Pearson correlation $=.79)$. 
Table 6

Pearson Correlation Test

\begin{tabular}{llcc}
\hline & & The Charisma of the Leader & Ability of the leader to lead in crisis \\
\hline The Charisma of the Leader & Pearson Correlation & 1 & $.79^{* *}$ \\
& Sig. (2-tailed) & & .00 \\
& $\mathrm{~N}$ & 70 & 70 \\
Ability of the leader to lead in crisis & Pearson Correlation & $.79^{* *}$ & 1 \\
& Sig. (2-tailed) & .00 & 70 \\
& $\mathrm{~N}$ & 70 & 70 \\
\hline
\end{tabular}

Note. ${ }^{* *}$ Correlation is significant at the 0.01 level (2-tailed).

This study aimed to shed light on the impact of a leader's charismatic influence on educators working at a distance amid the COVID-19 crisis. It evaluated the followers' perception, based on demographic variables, on charismatic leadership and the ability to lead during the several crises facing Lebanon. Researchers have often tackled similar topics, but the inconsistent results of their investigations have clouded the issue of when and how charisma matters in institutions. With this pandemic, the educational environment seemed receptive to leadership decisions that would lead to radical change. According to Meindl et al. (2001), such situations are best controlled by those deemed charismatic. A recent study done in Turkey showed that if educational leaders are planning major transformations within the organization, they should have the buyout from their followers due to their clear vision and purpose (Cetin \& Kinik, 2015). Thereby, evaluating the performance of the leader from the follower's perspective is fundamental. This research focused on the demographic variables of the followers and if these variables affect the educator's perception of his/her leader's character and performance under pressure. Two main demographic variables are under focus, the gender of followers and their level of education. The complex relationship between leadership and gender was first tackled by Kanter (1987); however, the literature predominantly studied the differences between male and female leadership methods and rarely discussed how male and female followers perceive their leaders.

$\mathrm{H}_{1}$ assumed that, when working in virtual teams, male educators perceive their leaders as charismatic more than females do. Nonetheless, this difference was deemed statistically insignificant. This result may be due to the small sample size. A larger sample could have yielded a more significant difference. The literature does not show any research on how virtual teams' perception of leadership styles differed with gender. However, a similar study was conducted by Mitevska-Encheva (2018) to evaluate the differences in perception of leadership styles between male and female educators in Bulgarian universities when on campus. Similarly, the results showed that the differences were not significant. $\mathrm{H}_{3}$ also rendered insignificant differences when comparing the educators' perception of leadership in crisis according to gender. But here, females seemed to believe that their leaders performed better during the COVID-19 pandemic than their male counterparts. This difference could be due to the nature of the female character, which tends to be more emotional during the crisis. The literature suggests that women are more sensitive than men to both verbal and non-verbal communication which allows them to infer the motive of the leader better (Chong \& Wolf, 2010; Falk, 1997). During a crisis, the leader should instill trust and confidence in employees. By gaining their trust, proper leadership can inspire a team effort strong enough to overcome the obstacles ahead (Anderson, 2018). Hofstede and McCrae (2004) suggested that personality traits, values, and culture were related to behavioral choices. Stereotypically, women are recognized as unselfish, friendly, nurturing, sensitive, cooperative, interdependent, and 
accepting of change. They tend to balance their work and family life and are more affected by crises than men (Fagan, 2001; Konrad et al., 2000; Roehling et al., 2001).

$\mathrm{H}_{2}$ and $\mathrm{H}_{4}$ test the effect of the followers' level of education on their leader's charisma and performance during crisis, respectively. For both hypotheses, the results showed that followers holding a Bachelor's degree perceived their leaders' character and performance better than their counterparts holding a Master's degree or a PhD, respectively. However, Levene's test deemed the difference insignificant. Again, this could be due to the small sample size studied. This study's results seem logical since the level of education represents the individual's level of maturity when it comes to assessing character and performance. An employee holding a bachelor's degree will see his leader from a shallower perspective and is easily emotionally intrigued by any effort exerted by the leader. On the other hand, the holder of a $\mathrm{PhD}$ has more experience and more developed work maturity to evaluate the leader's behavior and assess their actions. Moreover, followers with enough educational background in their field of work can pinpoint their leaders' character and performance strengths and weaknesses, becoming highly critical, which impacts their positive assessment. On the other hand, employees with a lower level of education, such as a bachelor's degree, have yet to acquire enough field knowledge and experience to evaluate their leader's behavior. In contrast, they acknowledge the leader as someone they look up to and learn from in the quest for growth and career advancement, neglecting any evident negative attributes. The literature shows several studies that support our view. Vecchio and Boatwright (2002) showed that followers with higher levels of education convey a lesser preference for leader behavior. Mitevska-Encheva (2018) found that the acceptance of the leadership style depended on the respondent's educational level.

$\mathrm{H}_{5}$ assumed that there is a positive correlation between charismatic leadership and the ability of the leader to perform during the crisis. The results showed that the hypothesis is accepted with a strong positive correlation between these two variables. Our findings support past research that always linked the charismatic nature of a leader to their positive influence on followers during a crisis (Alkhawlani et al., 2016; Fernandez \& Shaw, 2020a; Kakavogianni, 2009).

\section{Conclusions}

The study of leadership in organizations has rapidly evolved over the years, paving the way for exploring new methods and models applied in business research. The interest in Leadership studies has not diminished over the years, perhaps due to the strong positive effect proper leadership has on organizational outcomes (Wang et al., 2011). The majority of past research on leadership focused on the leader's behavior; seldom do they show interest in the followers' values, identities, and perception of the leader on follower behavior (Vondey, 2008). This study aimed to determine which followers' characteristics are determinants of their perception of the leaders in terms of charisma and the leader's performance during crises. The target organizations were non-vocational universities in Lebanon. The results showed that gender and level of experience do not significantly affect the followers' perception of their leader's charisma and ability to lead during the crisis. Also, a strong positive correlation was found between charismatic leadership and leading in crisis. In a stressful situation, such as the emergent COVID-19 pandemic, educational leaders faced an inevitable challenge to take unprecedented decisions to move to full-fledged online learning. This left their employees as virtual teams, and communication had to be through non-traditional means. At this point, it was up to the leader to rise up to the challenge or succumb under its heavyweight. With the pandemic overcasting its shadow on the world, communication was restricted to digital 
platforms. Such virtual meetings direct the focus on conversations to comprehend information, making projecting charisma a tough challenge (Fosslien \& Duffy, 2020; Sadler, 2020).

The theoretical and empirical findings of the study present several contributions. They foster our understanding of the relationship between the charismatic nature of the leader and his/her ability to lead an educational organization in crises and whether the followers' perception of leaders is affected by demographic differences such as gender and level of education. Moreover, these findings show that even when working at a distance, the leader's charisma can dissipate to his/her team members. This study also provided promising results despite the situation during which it was conducted and the relatively low number of respondents. One significant contribution provided by this work to the existing literature is the evaluation of leader's behavior from an educator's perspective when working at a distance, a topic that has been surprisingly understudied especially in Arab countries. We sought to examine how followers' perception of leaders is affected by demographic differences such as gender and level of education. The majority of the respondents in this study still sensed the charismatic impact of their leader through online meetings and other sources of communication such as emails. They also believe that their charismatic leaders succeeded in overcoming the hurdles set by the pandemic.

The data collection process faced myriad challenges due to a lack of stability in Lebanon's economic, political and socio-cultural situations. Moreover, a larger sample size could have produced more significant results regarding demographic variables. Future research is required to investigate whether such crises change the leader's behavior or the follower's perception of this behavior. Nonetheless, the results of this study constitute a cornerstone for future research that would investigate the impact of demographic variables on the followers' perception of their leaders' behavior in a more comprehensive manner. As aforementioned, this topic is under-researched, especially in the MENA region. Future studies may demonstrate whether a crisis changes the leader's behavior or the follower's perception of this behavior. Future research can, as well, replicate the present work but in better circumstances and on a larger scale to gather a larger number of respondents and achieve more significant results.

\section{References}

Alimo-Metcalfe, B. (2013). A critical review of leadership theory. In H. S. Leonard, R. Lewis, A. M. Freedman, \& J. Passmore (Eds.), Wiley-Blackwell handbooks in organizational psychology. The Wiley-Blackwell handbook of the psychology of leadership, change, and organizational development (p. 15-47). Wiley Blackwell. https://doi.org/10.1002/9781118326404.ch2

Alkhawlani, M. A. S., Haderi, S. M. A., bin Bohari, A. M., Ahmed, F. B., \& Rahim, N. F. A. (2016). Charisma leadership an important determinant for the crisis management. International Journal of Business and Social Science, 7(9), 126-136.

Almaiah, M. A., Al-Khasawneh, A., \& Althunibat, A. (2020). Exploring the critical challenges and factors influencing the Elearning system usage during COVID-19 pandemic. Education and Information Technologies, 25, 5261-5280.

Almanthari, A., Maulina, S., \& Bruce, S. (2020). Secondary school mathematics teachers' views on E-learning implementation barriers during the COVID-19 pandemic: the case of Indonesia. Eurasia Journal of Mathematics, Science and Technology Education, 16(7), em1860.

Anderson, L. (2018). Leadership during crisis. Leader to Leader, 2018(90), 49-54.

Antonakis, J. (2012). Transformational and charismatic leadership. The Nature of Leadership, 256-288. 
Avolio, B., \& Bass, B. (1995). Individual consideration viewed at multiple levels of analysis: A multi-level framework for examining the diffusion of transformational leadership. The Leadership Quarterly,6(2), 199-218. https://doi.org/10.1016/1048-9843(95)90035-7

Bass, B. M. (2000). The future of leadership in learning organizations. Journal of Leadership Studies, 7(3), 18-40.

Bass, B. M., \& Stogdill, R. M. (1990). Bass \& Stogdill's handbook of leadership: Theory, research, and managerial applications. Simon and Schuster.

Beaudoin, M. F. (2003). Distance education leadership for the new century. Online Journal of Distance Learning Administration, 6(2).

Beyer, J. M. (1999). Taming and promoting charisma to change organizations. The Leadership Quarterly, 10(2), 307-330.

Bolden, R., Gosling, J., Marturano, A., \& Dennison, P. (2003). A review of leadership theory and competency frameworks. Retrieved from http://hdl.handle.net/10036/17494

Brands, R. A., Menges, J. I., \& Kilduff, M. (2015). The leader-in-social-network schema: Perceptions of network structure affect gendered attributions of charisma. Organization Science, 26(4), 1210-1225.

Bryant, S. E. (2003). The role of transformational and transactional leadership in creating, sharing and exploiting organizational knowledge. Journal of Leadership \& Organizational Studies, 9(4), 32-44.

Center for Creative Leadership. (2020). Leadership Development Results That Matter | CCL | Learn More. Retrieved 29 September 2020, from https://www.ccl.org/.

Cetin, M. O., \& Kinik, F. S. F. (2015). An analysis of academic leadership behavior from the perspective of transformational leadership. Procedia-Social and Behavioral Sciences, 207, 519-527.

Cherry, K. (2019). Scribd.com. Retrieved 17 October 2020, from https://www.scribd.com/doc/117765913/Leadership-TheoriesEight-Major-Leadership-Theories.

Cherulnik, P. D., Donley, K. A., Wiewel, T. S. R., \& Miller, S. R. (2001). Charisma is contagious: The effect of leaders' charisma on observers' affect 1. Journal of Applied Social Psychology, 31(10), 2149-2159.

Chong, E., \& Wolf, H. (2010). Factors influencing followers' perception of organisational leaders. Leadership \& Organization Development Journal, 31(5), 402-419.

Conger, J. A. (1989). The charismatic leader: Behind the mystique of exceptional leadership. Jossey-Bass.

Conger, J. A., \& Kanungo, R. N. (1987). Toward a behavioral theory of charismatic leadership in organizational settings. Academy of Management Review, 12(4), 637-647.

Crayne, M. P., \& Medeiros, K. E. (2020). Making sense of crisis: Charismatic, ideological, and pragmatic leadership in response to COVID-19. American Psychologist. Advance online publication. https://doi.org/10.1037/amp0000715

Davis, K. M., \& Gardner, W. L. (2012). Charisma under crisis revisited: Presidential leadership, perceived leader effectiveness, and contextual influences. The Leadership Quarterly, 23(5), 918-933.

Duarte, D. L., \& Snyder, N. T. (2006). Mastering virtual teams: Strategies, tools, and techniques that succeed. John Wiley \& Sons.

Edmondson, A. (2020). Don't Hide Bad News in Times of Crisis. Harvard Business Review. Retrieved 14 August 2020 , from https://hbr.org/2020/03/dont-hide-bad-news-in-times-of-crisis.

Epley, J. L. (2015). Weber's theory of charismatic leadership: The case of Muslim leaders in contemporary Indonesian politics. International Journal of Humanities and Social Science, 5(7), 7-17.

Fagan, C. (2001). Time, money and the gender order: work orientations and working-time preferences in Britain. Gender, Work \& Organization, 8(3), 239-266.

Falk, D. (1997). Brain evolution in females. Women in Human Evolution, 114-136.

Fauzi, I., \& Khusuma, I. H. S. (2020). Teachers' elementary school in online learning of COVID-19 pandemic conditions. Jurnal Iqra': Kajian Ilmu Pendidikan, 5(1), 58-70.

Fernandez, A. A., \& Shaw, G. P. (2020a). Academic leadership in a time of crisis: The coronavirus and COVID-19. Journal of Leadership Studies, 14(1), 39-45.

Fernandez, A., \& Shaw, G. (2020b). Leadership in higher education in an era of adaptive challenges. Presented at the International Technology, Education and Development Conference (pp. 61-65). Valencia, Spain: IATED Academy.

Fiedler, F. E. (1964). A contingency model of leadership effectiveness. In Advances in experimental social psychology (Vol. 1, pp. 149-190). Academic Press.

Fiedler, F. E. (1967). A theory of leadership effectiveness. Mcgraw-Hill Series In Management.

Fiedler, F. E., \& Chemers, M. M. (1974). Leadership and effective management. Glenview, IL: Scott, Foresman and Co. 
Field, K. (2020). 5 Lessons from Campuses That Closed After Natural Disasters. CHE. Retrieved 15 August 2020, from https://www.chronicle.com/article/5-lessons-from-campuses-that-closed-after-natural-disasters/.

Fosslien, L., \& Duffy, M. (2020). How to Combat Zoom Fatigue. Harvard Business Review. Retrieved 3 June 2020, from https://hbr.org/2020/04/how-to-combat-zoom-fatigue.

Garcia, I. (2015). Emergent leadership: Is e-leadership importance in the quality of virtual education?. RIED: Revista Iberoamericana de educación a Distancia, 18(1), 25-44.

Gardner, W. L. (2003). Perceptions of leader charisma, effectiveness, and integrity: Effects of exemplification, delivery, and ethical reputation. Management Communication Quarterly, 16(4), 502-527.

Goodboy, A. K., \& Bolkan, S. (2011). Leadership in the college classroom: The use of charismatic leadership as a deterrent to student resistance strategies. The Journal of Classroom Interaction, 4-10.

Gunasekare, D. U. (2016). Self determination theory to explain charismatic leadership in virtual teams: Proposing an integrated model. International Journal of Business Administration, 7(3).

Hargreaves, A. (2000). Four ages of professionalism and professional learning. Teachers and Teaching, 6(2), 151-182.

Herman, H. M., \& Chiu, W. C. (2014). Transformational leadership and job performance: A social identity perspective. Journal of Business Research, 67(1), 2827-2835.

Hidayat, R., Patras, Y. E., Hardhienata, S., \& Agustin, R. A. (2020). The effects of situational leadership and self-efficacy on the improvement of teachers' work productivity using correlation analysis and SITOREM. COUNS-EDU: The International Journal of Counseling and Education, 5(1), 6-14.

Hoch, J. E., \& Dulebohn, J. H. (2017). Team personality composition, emergent leadership and shared leadership in virtual teams: A theoretical framework. Human Resource Management Review, 27(4), 678-693.

Hofstede, G., \& McCrae, R. R. (2004). Personality and culture revisited: Linking traits and dimensions of culture. Cross-cultural Research, 38(1), 52-88.

House, R. J. (1971). A path goal theory of leader effectiveness. Administrative Science Quarterly, 321-339.

House, R. J., Wright, N. S., \& Aditya, R. N. (1997). Cross-cultural research on organizational leadership: A critical analysis and a proposed theory. In P. C. Earley \& M. Erez (Eds.), The New Lexington Press management and organization sciences series and New Lexington Press social and behavioral sciences series. New perspectives on international industrial/ organizational psychology (p. 535-625). The New Lexington Press/Jossey-Bass Publishers.

Howell, J. M. (1997). Organization contexts, charismatic and exchange leadership. Kellogg Leadership Studies Monograph, Center for Political Leadership and Parti-citation. College Park, MD, Univ. of Maryland.

Hyland, P., Reeves, D., \& Caputo, A. (2018). Transformational and transactional leadership in today's work environment: A metaanalysis. Presented at the Society for Industrial and Organizational Psychology Conference. https://doi.org/10.13140/RG.2.2.33591.21921.

Irlbeck, S. (2002). Leadership and distance education in higher education: A US Perspective. The International Review of Research in Open and Distributed Learning, 3(2). https://doi.org/10.19173/irrodl.v3i2.91

Joosse, P. (2014). Becoming a God: Max Weber and the social construction of charisma. Journal of Classical Sociology, 14(3), 266-283.

Judge, T. A., \& Piccolo, R. F. (2004). Transformational and transactional leadership: a meta-analytic test of their relative validity. Journal of applied psychology, 89(5), 755-768.

Kakavogianni, D. (2009). Charismatic Leadership and its emergence under crisis conditions: A case study from the airline industry. Working Paper. University of York, The York Management School.

Kanter, R. M. (1987). Men and women of the corporation revisited: interview with Rosabeth Moss Kanter. Human Resource Management, 26(2), 257-263.

Kirel, C. (2007). Sanal örgütlerde örgütsel davranışın geleceği. [The future of organizational behavior in virtual organization]. Anadolu Üniversitesi Sosyal Bilimler Dergisi, 7(1), 93-110.

Kominiak, T. (2016). 3 Ways to be a more charismatic school leader. Trusted. Retrieved 19 July 2020, from http://trustedk12.com/3-ways-to-be-a-more-charismatic-school-leader/.

Konrad, A. M., Ritchie Jr, J. E., Lieb, P., \& Corrigall, E. (2000). Sex differences and similarities in job attribute preferences: a meta-analysis. Psychological bulletin, 126(4), 593-641.

Kreitner, R., \& Kinicki, A. (2004). Organizational behavior (6th ed.). The McGraw-Hill Companies.

Kull, S.L. (2003). The ameliorating effects of transformational leadership on resistance to change: transformational leadership and conductivity for schematic conversion (Unpublished Doctoral Dissertation). Regent University.

Kuscu, M., \& Arslan, H. (2016). Virtual leadership at distance education teams. Turkish Online Journal of Distance Education, 17(3). https://doi.org/10.17718/tojde.79230 
Kwan, P. (2020). Is transformational leadership theory passé? Revisiting the integrative effect of instructional leadership and transformational leadership on student outcomes. Educational Administration Quarterly, 56(2), 321-349.

Larson, L., Hunt, J., \& Osborn, R. (1974). Correlates of leadership and demographic variables in three organizational settings. Journal of Business Research, 2(3), 335-348. https://doi.org/10.1016/0148-2963(74)90009-5

Luenendonk, M. (2020). Charismatic Leadership Guide: Definition, Qualities, Pros \& Cons, Examples. Cleverism. Retrieved 2 October 2020, from https://www.cleverism.com/charismatic-leadershipguide/\#: :text=In\%201976\%2C\%20Robert\%20J.,to\%20a\%20more\%20testable\%20concept.

Mascolo, M. (2020). Transforming higher education: Responding to the coronavirus and other looming crises. Pedagogy and the Human Sciences, 7(1), 2.

Mehtab, K., ur Rehman, A., Ishfaq, S., \& Jamil, R. A. (2017). Virtual leadership: a review paper. Mediterranean Journal of Social Sciences, 8(4 S1), 183.

Meindl, J., Conger, J., \& Kanungo, R. (2001). Charismatic leadership in organizations. Administrative Science Quarterly, 46(1), 163. https://doi.org/10.2307/2667134.

Meslec, N., Curseu, P. L., Fodor, O. C., \& Kenda, R. (2020). Effects of charismatic leadership and rewards on individual performance. The Leadership Quarterly, 31(6), 101423.

Mitevska-Encheva, M. (2018). Effects of demographic indicators on perceptions of followers of leadership styles. Information \& Security, 39(1), 206-219.

Mulford, B. (2008). The leadership challenge: Improving learning in schools. Australian Council for Educational Research (ACER)

Mumford, M. D., Antes, A. L., Caughron, J. J., \& Friedrich, T. L. (2008). Charismatic, ideological, and pragmatic leadership: Multi-level influences on emergence and performance. The Leadership Quarterly, 19(2), 144-160.

Nastiezaie, N., \& Musavinejad, S. H. (2018). Predicting the effectiveness of school principals based on Fiedler's leadership model. The New Educational Review, 51(1), 184-191.

Northouse, P. G. (2010). Leadership: Theory and practice. Sage Publications.

Nworie, J., Haughton, N., \& Oprandi, S. (2012). Leadership in distance education: Qualities and qualifications sought by higher education institutions. American Journal of Distance Education, 26(3), 180-199.

OECD (2020). Improving School Leadership - Home - OECD. Oecd.org. Retrieved 17 August 2020, from http://www.oecd.org/education/school/improvingschoolleadership-

home.htm\#: :text=Effective\%20school\%20leadership\%20is\%20increasingly,different\%20approaches $\% 20$ to $\% 20$ school $\% 201$ eadership.>.

Olcott, D. (2020). In search of leadership: Practical Perspectives on leading distance education organisations. Asian Journal of Distance Education, 15(2), 48-57.

Otte, G., \& Benke, M. (2006). Online learning: New models for leadership and organization in higher education. Journal of Asynchronous Learning Networks, 10(2), 145-158.

Owusu-Fordjour, C., Koomson, C. K., \& Hanson, D. (2020). The impact of Covid-19 on learning-the perspective of the Ghanaian student. European Journal of Education http://dx.doi.org/10.46827/ejes.v0i0.3000

Rink, F., Stoker, J. I., Ryan, M. K., Steffens, N. K., \& Nederveen Pieterse, A. (2019). Gender differences in how leaders determine succession potential: The role of interpersonal fit with followers. Frontiers in Psychology, 10, 752. https://doi.org/10.3389/fpsyg.2019.00752

Robbins, S., \& Judge, T. (2018). Essentials of organizational behavior (14th ed.). Pearson Education Limited.

Roehling, P. V., Roehling, M. V., \& Moen, P. (2001). The relationship between work-life policies and practices and employee loyalty: A life course perspective. Journal of Family and Economic Issues, 22(2), 141-170.

Sadler, S. (2020). Council Post: How to Exhibit Charisma in A Virtual World. Forbes. Retrieved 21 July 2020, from https://www.forbes.com/sites/forbescoachescouncil/2020/07/08/how-to-exhibit-charisma-in-a-virtual-world/\#70c07f4f42ef.

Salehzadeh, R. (2017). Which types of leadership styles do followers prefer? A decision tree approach. International Journal of Educational Management. 31(7), 865-877. https://doi.org/10.1108/IJEM-04-2016-0079

Schratz, M. (2009). The role of school leadership in the improvement of learning. Tempus Public Foundation.I

VanSlyke, S., \& Simons, A. (2020). Leadership in the COVID-19 crisis. Controlrisks.com. Retrieved 21 July 2020, from https://www.controlrisks.com/our-thinking/insights/leadership-in-the-covid-crisis.

Vecchio, R. P., \& Boatwright, K. J. (2002). Preferences for idealized styles of supervision. The Leadership Quarterly, 13(4), 327342. 
Vergauwe, J., Wille, B., Hofmans, J., Kaiser, R. B., \& De Fruyt, F. (2018). The double-edged sword of leader charisma: Understanding the curvilinear relationship between charismatic personality and leader effectiveness. Journal of Personality and Social Psychology, 114(1), 110.

Vondey, M. (2008). Follower-focused leadership: Effect of follower self-concepts and self-determination on organizational citizenship behavior. Emerging Leadership Journeys, 1(1), 52-61.

Walsh, B. (2020). Covid-19: The history of pandemics. Bbc.com. Retrieved 29 July 2020, from https://www.bbc.com/future/article/20200325-covid-19-the-history-of-pandemics.

Wang, G., Oh, I. S., Courtright, S. H., \& Colbert, A. E. (2011). Transformational leadership and performance across criteria and levels: A meta-analytic review of 25 years of research. Group \& Organization Management, 36(2), 223-270.

Watkins, M., \& Yaziji, M. (2020). COVID-19 puts People and organizations under a lot of pressure. IMD business school. Retrieved 21 July 2020, from https://www.imd.org/research-knowledge/articles/COVID-19-under-pressure/.

Yaslioglu, M. M., \& SelenayErden, N. (2018). Transformational leaders in action: Theory has been there, but what about practice?. IUP Journal of Business Strategy, 15(1), 42-53.

Young, H. R., Glerum, D. R., Joseph, D. L., \& McCord, M. A. (2020). A meta-analysis of transactional leadership and follower performance: Double-edged effects of LMX and empowerment. Journal of Management, 47(5), 1255-1280.

Yukl, G. (2013). Leadership in organizations (8th ed.). Pearson Higher Education.

Zaleznik, A. (1990). The leadership gap. Academy Of Management, 4(1), 7-22.

Zhang, X., Liang, L., Tian, G., \& Tian, Y. (2020). Heroes or villains? The dark side of charismatic leadership and unethical proorganizational behavior. International Journal of Environmental Research and Public Health, 17(15), 5546. https://doi.org/10.3390/ijerph17155546 